\title{
PENERAPAN SISTEM BAGI HASIL PADA BANK SYARIAH DIKAITKAN DENGAN PERLINDUNGAN TERHADAP NASABAH (STUDI PADA BANK KALBAR SYARIAH PONTIANAK)
}

\author{
Herry Saderach \\ STT Eklesia Pontianak \\ Email: harry.sadrakh@ymail.com
}

\begin{abstract}
This study aim to express and analyze application system for result be linked with protection for the customer Bank of Islamic Kalbar, Pontianak. The kind of this method is qualitative with study of approach that is yuridical normative and also socio-legal, study and analyze laws and regulations existing is associated with condition in the field. The result of this study show in it practice, Bank of Islamic Kalbar Pontianak adhere to revenue sharing system, when saving fund can more is benefited because revenue sharing is counted from total revenue of bank before is reduced with operational costs. In general, this system is used by banks of Islamic in give revenue sharing for customer/depositor of funds, because if bank experience loss, depositor still will get revenue sharing. Beside that, Bank of Islamic kalbar as manager fund of customer give revenue sharing to fund deposit customer sourced from investation of bank for customer financing. From distribution fund/ investation of bank for public who need financing, bank get revenue sharing from the profit of customer bussiness. Bank of Islamic give revenue sharing to customer/depositor based on ratio/portion who have been agreed. For savings, it ratio 45\%:55\%, that is $45 \%$ to ratio of customer and $55 \%$ to portion of bank. While for depositor periode of time 1 month it ratio is $58 \%: 42 \%$ that means ratio/portion of customer is $58 \%$ while portion of bank is $42 \%$ from revenue who will be shared.
\end{abstract}

Keywords: Profit Sharing, Bank of Islamic, and Protection on Customer.

\begin{abstract}
Abstrak
Penelitian ini bertujuan untuk mengungkapkan dan menganalisis penerapan system bagi hasil dikaitkan dengan perlindungan terhadap nasabah pada Bank Kalbar Syariah Pontianak. Jenis metode penelitian ini kualitatif dengan studi pendekatan yuridis normative dan juga socio-legal, Mengkaji dan menganalisis peraturan perundang-undangan yang ada dikaitkan dengan kondisi dilapangan. Hasil penelitian ini menunjukkan dalam prakteknya, Bank Kalbar Syariah Pontianak menganut sistem Revenue Sharing, di mana penyimpan dana dapat lebih diuntungkan karena bagi hasil dihitung dari jumlah pendapatan bank sebelum dikurangi dengan biaya-biaya operasional. Pada umumnya sistem ini digunakan oleh bank-bank syariah dalam memberikan bagi hasil kepada nasabah/deposan penyimpan dana, karena apabila bank mengalami kerugian deposan tetap akan memperoleh pendapatan bagi hasil. Selain itu, Bank Kalbar Cabang Syariah sebagai pengelola dana nasabah memberikan bagi hasil kepada nasabah penyimpan dana yang bersumber dari investasi bank kepada nasabah pembiayaan. Dari penyaluran dana/investasi bank kepada masyarakat yang memerlukan pembiayaan, bank memperoleh pendapatan bagi hasil dari keuntungan usaha nasabah. Bank Syariah memberikan bagi hasil kepada nasabah/deposan berdasarkan nisbah/porsi yang telah disepakati. Untuk tabungan, nisbahnya 45\%: 55\%, yaitu 45\% untuk porsi nasabah dan untuk porsi bank sebesar 55\%. Sedangkan untuk deposito jangka waktu 1 bulan nisbahnya adalah 58\%: $42 \%$, artinya bagian/porsi nasabah 58\%, sedangkan porsi bank sebesar $42 \%$ dari pendapatan yang akan dibagihasilkan.
\end{abstract}

Kata Kunci: Bagi Hasil, Bank Syariah, dan Perlindungan Nasabah. 


\section{PENDAHULUAN}

Kegiatan usaha yang dominan dan sangat dibutuhkan oleh masyarakat dewasa ini dalam sector bidang lembaga keuangan salah satunya adalah jenis usaha dibidang lembaga keuangan. Peran lembaga keuangan ini dalam mempengaruhi pertumbuhan dan perkembangan ekonomi suatu bangsa sebagaimana dengan fungsinya adalah sebagai lembaga pengumpul dana. Sebagai alat penghimpun dana, lembaga keuangan ini mampu menggerakkan sektor pembangunan dengan menyalurkan dananya ke berbagai proyek penting di berbagai sektor usaha yang dikelola oleh pemerintah. Fungsi lain dari lembaga keuangan ini antara lain menyediakan dana bagi para pengusaha atau para pengusaha yang tingkat ekonominya lemah guna memperkuat dan keberlanjutan usahanya. Istilah lembaga keuangan atau bank adalah suatu jenis lembaga keuangan yang melaksanakan jasajasa keuangan yang beranekaragam, seperti memberi pinjaman, peredaran mata uang, menjalankan control terhadap mata uang, sebagai tempat penyimpanan barang berharga, dan ikut membiayai setiap jenis usaha suatu perusahaan (Abdurrachman, 1992).

Bank sebagian besar modalnya berasal dari masyarakat dalam bentuk simpanan giro, deposito, tabanas dan lainlain. Oleh karena itu, bank berkewajiban untuk memberi bunga kepada masyarakat yang bersangkutan serta berupaya untuk menjaga keselamatan modal agar tidak hilang. Salah satu bank yang berkembang di Indonesia saat ini adalah bank dengan prinsip syariah.

Lahirnya bank berdasarkan prinsip syariah di Indonesia telah telah berdampak positif dan juga memperkaya khasanah hukum dan memperjelas visi tentang bagaimana kehidupan dunia perbankan di Indonesia. Betapa tidak, karena sebagian besar penduduk bangsa Indonesia beragama Islam, sehingga kehadiran bank berdasarkan syariah yang notabene dilandasi unsur-unsur syariat Islam tersebut kehadirannya benar- benar ditunggu oleh sebagian besar masyarakat Indonesia.

Melihat maraknya perkembangan kehidupan bank-bank yang berdasarkan syariah di luar negeri, maka tidak perlu diragukan lagi bahwa kehadiran bank-bank tersebut di Indonesia sangat menjanjikan. Hanya saja, dalam proses perkembangannya di Indonesia tidak bisa dihindari akan berhadapan langsung dengan system hukum yang bukan sistem hukum islam murni, melainkan dalam perbankan dasar hukum yang digunakan adalah sistem perbankan konvensional yaitu dengan sistem bunga uang. Oleh sebab itu dibutuhkannya suatu gagasan atau ide secara yuridis untuk mempermudah kelancaran beroperasinya bank sesuai dengan prinsip syariah ini (Fuady, 2003).

Dengan dikeluarnya UndangUndang Nomor 10 Tahun 1998 tentang Perbankan, maka eksistensi bank-bank yang berdasarkan prisnip syariah ini dipertegas dan cakupan orientasi kegiatannya diperluas dari semula hanya bisa menjalankan sistem pembiayaan dengan prinsip bagi hasil, kemudian diubah menjadi melakukan pembiayaan dan/atau melakukan kegiatan (bukan hanya pembiayaan dengan bagi hasil) berdasarkan prinsip-prinsip syariah, di mana kegiatan-kegiatan tersebut telah ditetapkan oleh Bank Indonesia.

Dasar hukum utama bagi eksistensi bank berdasarkan syariah dapat dilihat dari ketentuan Pasal 6 huruf $m$ dan Pasal 13 huruf c Undang-Undang Nomor 10 Tahun 1998. Pasal 6 huruf m menyatakan bahwa Usaha Bank Umum meliputi: Menyediakan pembiayaan dan/atau melakukan kegiatan lain berdasarkan prinsip syariah, sesuai dengan ketentuan yang ditetapkan oleh Bank Indonesia. Sedangkan Pasal 13 huruf c menyatakan bahwa Bank Perkreditan Rakyat meliputi: menyediakan pembiayaan dan penempatan dana berdasarkan prinsip syariah sesuai dengan ketentuan yang ditetapkan oleh Bank Indonesia.

Menurut ketentuan dalam UndangUndang Nomor 10 tahun 1998, baik Bank 
Umum maupun Bank Perkreditan Rakyat boleh menerapkan prinsip syariah dalam mejalankan usaha di bidang jasa perbankan. Apabila nasabah menyimpan dana atau penerima kredit ingin menggunakan prinsip syariah, maka antara bank dan nasabah yang bersangkutan dibuat perjanjian tertulis yang memuat aturan perjanjian berdasarkan hukum Islam. Prinsip syariah ini di Indonesia mulai diterapkan di Bank Umum Indonesia dengan berdirinya Bank Muamalat Indonesia berdasarkan izin usaha dari Menteri Keuangan. Karena menerapkan prinsip syariah, maka Bank Umum yang bersangkutan sering disebut Bank Syariah (Abdulkadir \& Murniati, 2000).

PT. Bank Kalbar sebagai bank milik daerah juga mengikuti perkembangan munculnya perbankan dengan prinsip syariah, hal tersebut ditujukan dengan membuka unit usaha syariah Bank Kalbar dan Bank Kalbar Cabang Syariah Pontianak yang secara resmi dimulai sejak tanggal 12 Desember 2005. Berdasarkan Surat Izin Bank Indonesia nomor 7/24/DPwBz/DWBz/Ptk tanggal 1 Desember 2005. Latar belakang didirikannya Bank Kalbar Syariah ini dikarenakan bahwa Bank Pembangunan Daerah memiliki daya gravitasi lokal yang tinggi, adanya kebutuhan jasa perbankan bagi masyarakat yang tidak dapat menerima konsep bunga uang, ingin meresponisasi arah pasar dan memperdalam target pasar yang selama ini belum tercapai oleh pelaku pasar konvensional Bank Kalbar, dan karakteristik perbankan syariah yang bersifat universal dan bisa diterima lintas strata maupun agama.

Bank Kalbar Cabang Syariah sebagai pengelola dana nasabah (mudharib) memberikan bagi hasil kepada nasabah penyimpan dana (shahibul maal) yang bersumber dari investasi bank kepada nasabah pembiayaan. Dari penyaluran dana/investasi bank kepada masyarakat yang memerlukan pembiayaan, bank memperoleh pendapatan bagi hasil dari keuntungan (profit) usaha nasabah. Bank
Syariah memberikan bagi hasil kepada nasabah/deposan berdasarkan nisbah/porsi yang telah disepakati. Sebagai contoh untuk tabungan nisbah 45\%: $55 \%$, yaitu $45 \%$ untuk porsi nasabah, dan untuk porsi bank sebesar 55\%. Sedangkan untuk deposito jangka waktu 1 (satu) bulan nisbahnya adalah 58\% : 42\%, artinya bagian/porsi nasabah $58 \%$, sedangkan porsi bank sebesar $42 \%$ dari pendapatan yang akan dibagihasilkan.

Sistem bagi hasil yang diterapkan pada Bank Kalbar Syariah Pontianak ada 2 (dua), yaitu:

\section{Revenue Sharing}

Bank Syariah lebih sering menggunakan sistem ini, karena dalam sistem ini penyimpan dana dapat lebih diuntungkan karena bagi hasil dihitung dari jumlah pendapatan bank sebelum dikurangi dengan biaya-biaya operasional. Pada umumnya sistem ini digunakan oleh bank-bank syariah dalam memberikan bagi hasil kepada nasabah/deposan penyimpan dana, karena apabila bank mengalami kerugian deposan tetap akan memperoleh pendapatan bagi hasil.

\section{Profit/Loss Sharing}

Dalam sistem ini cara penghitungan bagi hasilnya berdasarkan jumlah pendapatan dikurangi dengan biayabiaya operasional sehingga bagi hasil yang didapat oleh penyimpan dana akan lebih kecil.

Dari uraian latar belakang di atas terlihat bahwa di satu sisi sistem bagi hasil yang diterapkan pada Bank Kalbar Cabang Syariah Pontianak memberikan keuntungan yang besar kepada nasabah, sedangkan di sisi lain ada juga sistem yang memberikan keuntungan yang lebih kecil kepada nasabah.

\section{METODE PENELITIAN}

\section{Metode Pendekatan}

Penelitian ini dapat dilakukan melalui pendekatan utama yaitu Yuridis dan kepustakaan. Namun pendalaman 
lebih lanjut penulis merasa perlu ditunjang dengan pendekatan sosiologi legal. Penelitian bersifat yuridis/normatif oleh karena sasaran penelitian ini adalah hukum atau kaidah (norm). Pengertian kaidah di sini meliputi asas hukum, kaidah hukum dalam arti nilai, pengaturan hukum konkrit dan sistem hukum. Berkaitan dengan penelitian hukum normatif obyeknya berupa asasasas hukum, sistematika hukum, taraf sinkronisasi vertikal dan horizontal (Mertokusumo, 1996).

Penelitian ini juga bersifat sosiologi legal yang berdasarkan kajian pada pelaksanaan hukum dalam masyarakat, dengan mengkaji realitas empirik yang dilakukan dalam level analisis mikro, dengan melihat hukum sebagai paradigma definisi sosial. Pendekatan sosiologi legal ini lebih menitikberatkan pada aspek makna hokum melihat aksi dan perilaku masyarakat (perbankan).

\section{Lokasi Penelitian}

Penelitian ini dilaksanakan di Bank Kalbar Syariah Pontianak, karena Bank Kalbar merupakan bank milik daerah dan dalam perkembangannya Bank Kalbar Syariah Pontianak cukup banyak diminati oleh warga masyarakat dalam memberikan layanan jasa perbankan

\section{Populasi dan Sampel}

Populasi dalam penelitian ini adalah Pimpinan Bank Indonesia Cabang Pontianak, Pimpinan PT. Bank Kalbar Pontianak, Kepala Divisi Unit Usaha Syariah Bank Kalbar Cabang Pontianak, dan Nasabah Bank Kalbar Syariah Pontianak.

Metode sampling yang dipergunakan adalah Purposive Sampling (sampel bertujuan) karena sampel yang diperlukan dalam penelitian ini harus memiliki karakteristik tertentu sesuai dengan tujuan penelitian. Berdasarkan teknik sampling di atas, maka yang menjadi sampel dalam penelitian ini adalah:
1) Pimpinan Bank Indonesia Cabang Pontianak,

2) Pimpinan PT. Bank Kalbar Pontianak

3) Kepala Divisi Unit Usaha Syariah Bank Kalbar Cabang Pontianak.

4) 5 (lima) orang Nasabah Bank Kalbar Syariah Pontianak.

\section{Teknik dan Alat Pengumpul Data}

a. Untuk pengumpulan dana sekunder dilakukan dengan penelitian kepustakaan (Library Research) yaitu penelitian data melalui studi pustaka terhadap peraturan perundangundangan, dokumen-dokumen atau catatan, literatur serta hasil penelitian yang berkaitan dengan masalah penelitian ini.

b. Untuk pengumpulan data primer dilakukan dengan menggunakan wawancara. Wawancara dalam penelitian ini digunakan metode wawancara tak berstruktur yaitu pertanyaan diajukan secara lebih bebas dan leluasa, tanpa terikat oleh susunan pertanyaan yang telah dipersiapkan sebelumnya, dengan tujuan agar arahnya lebih terbuka dan bisa didapatkan informasi yang lebih luas, serta wawancara dapat berlangsung secara luwes.

\section{Analisis Data}

Analisis masalah dan kolerasinya dengan data yang dihimpun akan dilakukan dengan menggunakan pendekatan analisis deskriptif yuridis dan sosiologis kualitatif.

\section{PEMBAHASAN DAN DISKUSI}

A. Analisis Penerapan Sistem Bagi Hasil Dikaitkan Dengan Perlindungan Terhadap Nasabah Pada Bank Kalbar Syariah Pontianak

Prinsip bagi hasil (sharing profit) merupakan karakteristik umum dan landasan dasar bagi operasional bank Islam secara keseluruhan. Secara syariah, dalam prinsipnya berdasarkan kaidah almudharabah. Berdasarkan prinsip ini, 
bank syariah berkedudukan sebagai sebagai mitra kerjasama, baik dengan nasabah maupun dengan pengusaha yang meminjam dana. Dengan nasabah, bank akan bertindak sebagai pengelola (mudharib), sedangkan nasabah bertindak sebagai penyandang dana (shahibul maal). Antara keduanya diadakan akad perjanjian mudharabah yang dijelaskan dalam akad tersebut pembagian keuntungan masing-masing pihak. Atau suatu akad kerjasama dalam suatu usaha antara dua belah pihak dimana pihak pertama (malik, Shahib al mal, Lembaga Keuangan Syariah) menyediakan seluruh modal, sedangkan pihak kedua (amil, mudharib, nasabah) bertindak selaku pengelola, dan keuntungan usaha dibagi di antara mereka sesuai kesepakatan yang dituangkan dalam kontrak.

Di lain pihak, dalam penerapan sistem bagi hasil pada bank syariah selalu dipengaruhi oleh 2 (dua) faktor, antara lain sebagai berikut:

1. Faktor Langsung

Faktor langsung (direct factors) yang mempengaruhi perhitungan bagi hasil adalah investment rate, jumlah dana yang tersedia dan nisbah bagi hasil (profit sharing ratio).

a. Investment rate merupakan persentase aktual dana yang diinvestasikan dari total dana. Jika bank menentukan investemen rate sebesar 80 persen, hal ini berarti 20 persen dari total dana dialokasikan untuk memenuhi likuiditas.

b. Jumlah dana yang tersedia untuk diinvestasikan merupakan juml ah dana dari berbagai sumber dana yang tersedia untuk diinvestasikan. Dana tersebut dapat dihitung dengan menggunakan salah satu metode ini:
1) rata-rata saldo minimum
bulanan;

2) rata-rata total saldo harian.

Investment rate dikalikan dengan jumlah dana yang tersedia untuk diinvestasikan, akan menghasilkan jumlah dana aktual yang digunakan.

c. Nisbah (profit sharing ratio)

1) Salah satu ciri almudharabah adalah nisbah yang harus ditentukan dan disetujui pada awal perjanjian.

2) Nisbah antara satu bank dan bank lainnya dapat berbeda.

3) Nisbah juga dapat berbeda dari waktu ke waktu dalam satu bank, misalnya deposito 1 bulan, 3 bulan, 6 bulan, dan 12 bulan.

4) Nisbah juga dapat berbeda antara satu account dan account lainnya sesuai dengan besarnya dana dan jatuh temponya.

2. Faktor Tidak Langsung

a. Penentuan butir-butir pendapatan dan biaya mudharabah

Bank dan nasabah melakukan share dalam pendapatan dan biaya (profit and sharing). Pendapatan yang "dibagihasilkan" merupakan pendapatan yang diterima dikurangi biaya-biaya. Jika biaya semua ditanggung bank, hal ini disebut revenue sharing.

b. Kebijakan akunting (prinsip dan metode akunting)

Bagi hasil secara tidak langsung dipengaruhi oleh bedalannya aktivitas yang diterapkan, terutama sehubungan dengan pengakuan pendapatan dan biaya.

Berdasarkan hasil wawancara dengan Bapak Muhammad Haddad, SE., selaku Kepala Divisi Unit Syariah Bank 
Kalbar diketahui bahwa dalam prakteknya, Bank Kalbar Syariah Pontianak menganut sistem Revenue Sharing, di mana penyimpan dana (nasabah) dapat lebih diuntungkan karena bagi hasil dihitung dari jumlah pendapatan bank sebelum dikurangi dengan biaya-biaya operasional. Pada umumnya sistem ini digunakan oleh bank-bank syariah dalam memberikan bagi hasil kepada nasabah/deposan penyimpan dana, karena apabila bank mengalami kerugian deposan tetap akan memperoleh pendapatan bagi hasil.

Berdasarkan penelitian dan pengamatan yang penulis lakukan di Bank Kalbar Syariah Pontianak, penulis menyimpulkan bahwa penerapan sistem bagi hasil pada Bank Kalbar Syariah Pontianak sudah sesuai dan sejalan dengan tuntunan Syariah Islam. Hal ini didasarkan pada alasan bahwa kegiatan yang dilakukan oleh Bank Kalbar Syariah Pontianak sudah mengacu kepada syariat Islam dan pengawasannya dilakukan oleh Dewan Pengawas Syariah (DPS).

Dalam kaitannya dengan perlindungan terhadap nasabah, Bank Kalbar Syariah Pontianak sudah memberikan perlindungan melalui penerapan sistem bagi hasil (nisbah) dengan nisbah/porsi yang disesuaikan dengan keuntungan yang diperoleh oleh Bank.

Bagi hasil (nisbah) yang diberikan oleh Bank Kalbar Syariah Pontianak adalah sebagai berikut:

a. Untuk Tabungan Mudharabah $=55 \%$ Bank : $45 \%$ Nasabah

b. Untuk Deposito

1 bulan $=42 \%$ Bank : $58 \%$ Nasabah

3 bulan $=41 \%$ Bank : 59\% Nasabah

6 bulan $=40 \%$ Bank : $60 \%$ Nasabah

12 bulan $=39 \%$ Bank : $61 \%$ Nasabah

Penghitungan sistem bagi hasil (nisbah) yang diberikan Bank Kalbar Syariah Pontianak kepada nasabah didasarkan pada:
5) Overhead Fix Cost

6) Operational Cost

7) Variable Cost

Di lain pihak, apabila dilihat secara jelas sebenarnya penerapan sistem bagi hasil pada Bank Syariah lebih menguntungkan dibanding sistem bunga yang diterapkan oleh bank konvensional. Hal ini dapat dilihat pada contoh perbandingan nisbah dan bunga deposito antara bank syariah dan bank konvensional.

Perbandingan Nisbah dan Bunga

Deposito antara Bank Syariah dan Bank

Konvensional

\begin{tabular}{|c|c|}
\hline $\begin{array}{c}\text { BANK } \\
\text { SYARIAH }\end{array}$ & $\begin{array}{c}\text { BANK } \\
\text { KONVENSIONAL }\end{array}$ \\
\hline 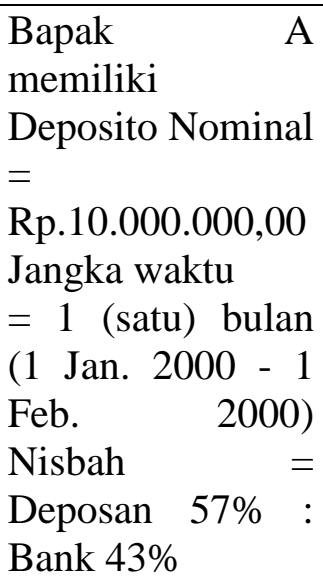 & $\begin{array}{l}\text { Bapak B Memiliki } \\
\text { Deposito Nominal } \\
=\quad \text { Rp. } \\
\text { 10.000.000,00 } \\
\text { Jangka Waktu = } 1 \\
\text { (Satu) Bulan }(1 \\
\text { Jan. 2000 - } 1 \text { Feb. } \\
\text { 2000) bunga = 20\% } \\
\text { p.a. }\end{array}$ \\
\hline 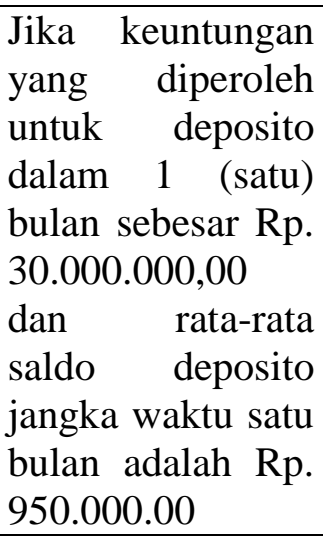 & \\
\hline $\begin{array}{l}\text { Pertanyaan: } \\
\text { berapa } \\
\text { keuntungan yang } \\
\text { diperoleh Bapak } \\
\text { A ? Jawab: } \\
\text { Rp. (10.000.000 : } \\
\text { 950.000) X }\end{array}$ & 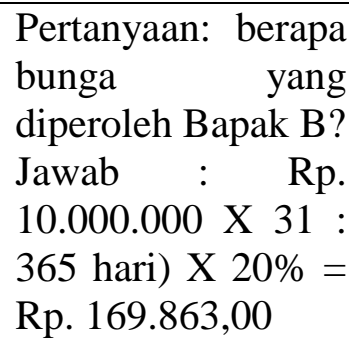 \\
\hline
\end{tabular}


Rp. $30.000 .000 \mathrm{X}$ $57 \%$

Rp. 180.000 .00

B. Kendala-kendala Yang Dihadapi Oleh Bank Kalbar Syariah Dalam Pengelolaan Bank Syariah Dikaitkan Dengan Perlindungan Terhadap Nasabah

Keberadaan Bank Syariah semakin mantap setelah lahir Undang-Undang Nomor 10 Tahun 1998 yang secara tegas mengakui keberadaan Bank Syariah, perkembangan dunia perbankan syariah di Indonesia cukup menggembirakan. Bank Syariah perlu dikembangkan di Indonesia karena memiliki keunggulan komparatif dibanding Perbankan Konvensional, baik di pusat maupun daerah.

Tujuan pengembangan sistem Perbankan Syariah, antara lain sebagai berikut (Dewi, 2004).

1. Untuk memenuhi kebutuhan jasa perbankan bagi masyarakat yang tidak dapat menerima konsep bunga dan mobilisasi dana masyarakat dapat dilakukan lebih optimal bagi segmen masyarakat yang selama ini belum dapat disentuh oleh sistem Perbankan Konvensional.

2. Peluang pembiayaan bagi pengembangan usaha berdasarkan prinsip kemitraan (mutual investor relationship).

Kebutuhan akan produk dan jasa perbankan yang memiliki keunggulan yang unik dan berlandaskan kepada nilai-nilai moral (peniadaan pembebanan bunga yang berkesinambungan/Perpectual Interest Effect dan mencegah terjadinya kerusakan lingkungan dan kerusakan moral).

Strategi

perbankan syariah dilakukan secara

komprehensif dan mengacu pada analisis kekuatan dan kelemahan perbankan syariah saat ini. Dari analisis tersebut diketahui terdapat beberapa kendala yang dihadapi dalam pengembangan perbankan syariah (Dewi, 2004), yaitu:

1. Masih terbatasnya jaringan kantor bank syariah, keterbatasan jaringan kantor ini sangat berpengaruh terhadap kemampuan pelayanan bank syariah terhadap masyarakat yang menginginkan jasa bank syariah.

2. Masih terbatasnya pemahaman masyarakat mengenai kegiatan usaha bank syariah, keterbatasan informasi mengenai bank syariah ini menyebabkan masih banyaknya masyarakat memiliki persepsi yang keliru mengenai operasi bank syariah.

3. Masih belum lengkapnya ketentuanketentuan tentang kegiatan usaha bank syariah, seperti standar akuntansi, standar prinsip kehatihatian, standar fatwa produk bank syariah, serta ketentuan pendukung lainnya.

4. Masih terbatasnya sumber daya manusia yang memiliki keterampilan teknis bank syariah.

Berdasarkan hasil wawancara dengan Bapak Muhammad Haddad, SE., berkenaan dengan kendala-kendala yang dihadapi oleh Bank Kalbar Syariah dalam pengelolaan bank syariah dikaitkan dengan perlindungan terhadap nasabah diperoleh data bahwa:

1. Tidak adanya kepastian dalam penentuan nisbah (bagi hasil), maksudnya nisbah (bagi hasil) dapat berubah sewaktu-waktu sehingga tidak ada kepastian bagi nasabah hal ini berbeda dengan sistem bunga yang diterapkan oleh bank konvensional, di mana bunga ditetapkan secara pasti.

2. Dalam membantu pembiayaan bagi usaha kecil dan menengah, Bank Kalbar Syariah kesulitan untuk 
memperoleh pembukuan neraca rugi laba dari nasabah sehingga pembiayaan yang seharusnya dapat diberikan menjadi terhambat.

3. Kondisi perekonomian dan perdagangan yang tidak menentu, sehingga mengakibatkan Bank Kalbar Syariah harus berhati-hati dalam membantu pembiayaan bagi usaha kecil dan menengah.

\section{Upaya-Upaya Yang Dilakukan Oleh Bank Kalbar Syariah Dalam Memberikan Perlindungan Terhadap Nasabah Dalam Pengelolaan Bank Syariah}

Pada dasarnya, bank sebagai lembaga keuangan yang usaha pokoknya adalah menghimpun dana dari dan menyalurkan dana kepada masyarakat dalam bentuk kredit dan atau bentuk-bentuk lainnya.

Metode penghimpunan dana yang ada pada Bank-bank konvensional didasari pada transaksi, cadangan dan investasi. Oleh karena itu, produk penghimpunan danapun berupa giro, tabungan dan deposito.

Berbeda dengan bank syariah yang tidak melakukan pendekatan tunggal dalam menyediakan produk penghimpunan dana bagi nasabahnya. Sebagai salah satu lembaga yang berfungsi untuk menghimpun dana masyarakat, bank syariah harus memiliki sumber dana yang optimal sebelum disalurkan kembali ke masyarakat. Di samping itu, sebagai bank syariah yang dituntut untuk mempraktekkan kaidah syariat Islam, maka perlu dipahami terlebih dahulu dana masyarakat dan transaksi-transaksi yang tidak bertentangan dengan syariat Islam. Sumber dana yang dapat dihimpun dari masyarakat terdiri dari 3 (tiga) jenis, yaitu:

1. Dana modal yaitu dana dari pendiri bank dan dari pemegang saham bank tersebut.
2. Dana titipan (Al-Wadi'ah) masyarakat baik yang dikelola oleh bank dengan sistem Wadi'ah maupun yang diinvestasikan melalui bank dalam bentuk dana investasi khusus (Mudharabah Muqayadah) atau investasi terbatas (Mudharabah Mutlaqah) serta,

3. Dana zakat, infaq dan sadaqah (Tim Pengembangan Perbankan Syariah, 1999: 24).

Pembiayaan merupakan salah satu tugas pokok bank, yaitu memberikan fasilitas penyediaan dana untuk memenuhi kebutuhan pihak-pihak yang memerlukan bantuan pembiayaan. Menurut sifat penggunaannya, pembiayaan dapat dibagi menjadi 2 (dua) hal berikut:

a. Pembiayaan produktif, yaitu pembiayaan yang ditujukan untuk memenuhi kebutuhan produksi dalam arti luas, yaitu untuk peningkatan usaha, baik usaha produksi, perdagangan, maupun investasi.

b. Pembiayaan konsumtif, yaitu pembiayaan yang digunakan untuk memenuhi kebutuhan konsumsi, yang akan habis digunakan untuk memenuhi kebutuhan.

Menurut keperluannya, pembiayaan produktif dapat dibagi menjadi 2 (dua), yaitu:

1) Pembiayaan modal kerja, yaitu pembiayaan untuk memenuhi kebutuhan;

a peningkatan produksi, baik secara kuantitatif, yaitu jumlah hasil produksi, maupun secara kualitatif yaitu peningkatan kualitas atau mutu hasil produksi; dan

b untuk keperluan perdagangan atau peningkatan utility of place dari suatu barang.

2) Pembiayaan invetasi, yaitu untuk memenuhi kebutuhan barang-barang modal (capital goods) serta fasilitas- 
fasilitas yang erat kaitannya dengan itu.

3) Pembiayaan modal kerja

Pembiayaan modal kerja dengan prinsip jual beli ditujukan untuk memiliki barang, sedangkan yang menggunakan prinsip sewa ditujukan untuk mendapatkan jasa. Prinsip bagi hasil digunakan untuk usaha kerja sama yang ditujukan guna mendapatkan barang dan jasa sekaligus. Bank syariah mempunyai mekanisme tersendiri untuk memenuhi kebutuhan pendanaan persedian tersebut, yaitu antara lain dengan menggunakan prinsip jual beli (al-bai) dalam 2 (dua) tahap. Tahap Pertama, bank mengadakan (membeli dari suplier secara tunai) barang-barang yang dibutuhkan oleh nasabah. Tahap Kedua, bank menjual kepada nasabah pembeli dengan pembayaran tangguh dan mengambil keuntungan yang disepakati bersama antara bank dan nasabah.

Dalam kaitannya dengan upayaupaya yang dilakukan oleh Bank Kalbar Syariah dalam memberikan perlindungan terhadap nasabah dalam pengelolaan Bank Syariah, berdasarkan hasil wawancara dengan Bapak Muhammad Haddad, SE., selaku Kepala Divisi Unit Syariah Bank Kalbar, diperoleh data bahwa:

1. Dalam setiap menghimpun dana dari nasabah dan menyalurkan dana kepada nasabah, Bank Kalbar Syariah membuat akad (murabahah, mudharabah dan musyarakah) yang isinya memuat ketentuan tentang hak dan kewajiban yang harus dipikul oleh Bank (Shahibul Maal) dan Nasabah (Mudharib) maupun kesepakatan bagi hasil sesuai dengan syariah Islam. Dengan adanya akad ini, maka nasabah telah mendapatkan perlindungan karena kedudukan Bank (Shahibul Maal) dan Nasabah (Mudharib) seimbang.
2. Setiap akad yang dibuat oleh Bank (Shahibul Maal) dan Nasabah (Mudharib), akan dilakukan pengawasan oleh Dewan Pengawas Syariah dari Bank Kalbar Syariah. Hal ini dilakukan untuk menghindari terjadinya perhitungan bagi hasil (nisbah) yang membuat nasabah menjadi rugi.

3. Dalam menghimpun dana, Bank Kalbar Syariah memberikan jaminan terhadap simpanan nasabah yaitu dengan menyetorkan simpanan nasabah kepada Lembaga Penjamin Simpanan (LPS).

Dari hal-hal yang dikemukakan di atas, tampak jelas bahwa Bank Kalbar Syariah Pontianak dalam mengelola bank yang menganut prinsip syariah telah memberikan perlindungan terhadap nasabah.

\section{KESIMPULAN}

Dari uraian-uraian yang telah penulis uraikan pada bab analisis hasil penelitian dan pembahasan, maka dapat ditarik kesimpulan sebagai berikut:

1. Dalam prakteknya, Bank Kalbar Syariah Pontianak menganut sistem Revenue Sharing, di mana penyimpan dana (nasabah) dapat lebih diuntungkan karena bagi hasil dihitung dari jumlah pendapatan bank sebelum dikurangi dengan biaya-biaya operasional. Pada umumnya sistem ini digunakan oleh bank-bank syariah dalam memberikan bagi hasil kepada nasabah/deposan penyimpan dana, karena apabila bank mengalami kerugian deposan tetap akan memperoleh pendapatan bagi hasil. Selain itu, Bank Kalbar Cabang Syariah sebagai pengelola dana nasabah (mudharib) memberikan bagi hasil kepada nasabah penyimpan dana (shahibul maal) yang bersumber dari investasi bank kepada nasabah pembiayaan. Dari penyaluran dana/investasi bank kepada masyarakat yang memerlukan pembiayaan, bank 
memperoleh pendapatan bagi hasil dari keuntungan (profit) usaha nasabah. Bank Syariah memberikan bagi hasil kepada nasabah/deposan berdasarkan nisbah/porsi yang telah disepakati. Untuk tabungan, nisbahnya 45\%: 55\%, yaitu $45 \%$ untuk porsi nasabah dan untuk porsi bank sebesar 55\%. Sedangkan untuk deposito jangka waktu 1 (satu) bulan nisbahnya adalah $58 \%$ : $42 \%$, artinya bagian/porsi nasabah $58 \%$, sedangkan porsi bank sebesar $42 \%$ dari pendapatan yang akan dibagihasilkan.

2. Kendala-kendala yang dihadapi oleh Bank Kalbar Syariah dalam pengelolaan bank syariah dikaitkan dengan perlindungan terhadap nasabah adalah:

a. Tidak adanya kepastian dalam penentuan nisbah (profit), maksudnya nisbah (profit / bagi hasil pendapatan) dalam skim pembiayaan dapat berubah sewaktu-waktu sehingga tidak ada kepastian bagi nasabah hal ini berbeda dengan sistem bunga yang diterapkan oleh bank konvensional, di mana bunga ditetapkan secara pasti atau fix.

b. Dalam membantu pembiayaan bagi usaha kecil dan menengah, Bank Kalbar Syariah kesulitan untuk memperoleh pembukuan neraca rugi laba dari nasabah sehingga pembiayaan yang seharusnya dapat diberikan menjadi terhambat.

c. Kondisi perekonomian dan perdagangan yang tidak menentu, sehingga mengakibatkan Bank Kalbar Syariah harus berhati-hati dalam membantu pembiayaan bagi usaha kecil dan menengah.

3. Upaya-upaya yang dilakukan oleh Bank Kalbar Syariah dalam memberikan perlindungan terhadap nasabah dalam pengelolaan Bank Syariah adalah:

a. Dalam setiap menghimpun dana dari nasabah dan menyalurkan dana kepada nasabah, Bank Kalbar
Syariah membuat akad (murabahah, mudharabah dan musyarakah) yang isinya memuat ketentuan tentang hak dan kewajiban yang harus dipikul oleh Bank (Shahibul Maal) dan Nasabah (Mudharib) maupun kesepakatan bagi hasil sesuai dengan syariah Islam. Dengan adanya akad ini, maka nasabah telah mendapatkan perlindungan karena kedudukan Bank (Shahibul Maal) dan Nasabah (Mudharib) seimbang.

b. Setiap akad yang dibuat oleh Bank (Shahibul Maal) dan Nasabah (Mudharib), akan dilakukan pengawasan oleh Dewan Pengawas Syariah dari Bank Kalbar Syariah. Hal ini dilakukan untuk menghindari terjadinya perhitungan bagi hasil (nisbah) yang membuat nasabah menjadi rugi.

c. Dalam menghimpun dana, Bank Kalbar Syariah memberikan jaminan terhadap simpanan nasabah yaitu dengan menyetorkan simpanan nasabah kepada Lembaga Penjamin Simpanan (LPS).

d. Potensi kerugian shahibul maal dan mudharib dapat ditutupi oleh bank sebagai pemilik dana. Karena biaya potensi kerugian yang dilakukan mudharib yang diakibatkan faktor ketidaksengajaan, diperoleh/ditutupi bank dari selisih bagi hasil.Dana inilah yang digunakan bank untuk melindungi nasabah/mudharib dalam menjalankan Syariah.

\section{DAFTAR PUSTAKA}

Abdurrachman, A. (1982). Ensiklopedia ekonomi, keuangan dan perdagangan:(Inggeris-Indonesia).

Pradnya paramita.

Abdulkadir, M., \& Murniati, R. (2000). Segi Hukum Lembaga Keuangan dan Pembiayaan. Bandung: Citra Aditya Bakti. 
Antonio, Muhammad Syafii. Bank Syari'ah dari Teori ke Praktek. Jakarta: Gema Insani Press, 2001.

Ascarya. (2011). Akad dan Produk Bank Syariah. Jakarta: PT RajaGarafindo Persada.

Dewi, G. (2004). Aspek-aspek hukum dalam perbankan dan perasuransian syariah di Indonesia. Jakarta: Prenada Media.

Djamil, Fathurrahman. (2012). Peneraapan Hukum Perjanjian dalam Transaksi di Lembaga Keuangan Syariah. Jakarta: Sinar Grafika.

Ismail. (2013). Perbankan Syariah. Jakarta: Kencana Prenamedia.

Karim, Adiwarman. (2004). Bank Islam: Analisis Fiqh dan Keuangan. Jakarta: PT RajaGrafindo Persada.

Linata, Ika Fitri Afri. (2016). "Implementasi fatwa DSN-MUI nomor 4/DSNMUI/IV/2000 pada pembiayaan Murabahah di BMT "Surya Mandiri" Mlarak Ponorogo", Disertasi. Ponorogo: IAIN Ponorogo.

Mardani. Fiqh Ekonomi Syariah: Fiqh Muamalah. Jakarta: Kencana, 2012.

Mertokusumo, S. (1996). Penemuan Hukum suatu pengantar. Yogyakarta: liberty.

Fuady, M. (2003). Aliran Hukum Kritis (Paradigma Ketidakberdayaan Hukum). Citra Aditya Bakti.

Peraturan Pemerintah nomor 72/ 1992, tentang Bank Berdasarkan Prinsip Bagi Hasil.

Peraturan Bank Indonesia nomor 32/34/KEP/DIR/1999 tentang Bank Umum Berdasarkan Syariah.

Peraturan Bank Indonesia Nomor 5/3/PBI/2003 tentang Fasilitas Pembiayaan Jangka Pendek Bagi Bank Syariah.

Peraturan Bank Indonesia Nomor: 6/17/PBI/2004 tentang Bank Perkreditan Rakyat Berdasarkan Prinsip Syariah.

Peraturan Bank Indonesia Nomor: 6/12/PBI/2004 tentang Giro Wajib Minimum dalam rupiah dan valuta asing Bagi Bank Umum yang melaksanakan kegiatan Usaha Berdasarkan Prinsip Syariah.

Suhendi, Hendi. (2004). BMT Bank Islam (Instrumen Lembaga Keuangan Syariah). Bandung: Pustaka Bani Quraisy.

Undang-Undang Nomor 10 Tahun 1998 tentang Perbankan.Perubahan atas Undang-undang 7 tahun 1992.

Yaya, Rizal, et.al. (2013). Akuntansi Perbankan Syariah: Teori dan Praktik Kontemporer. Jakarta: Salemba Empat.

Zainuddin. (2010). Hukum Perbankan Syariah. Jakarta: Sinar Grfika. 